American Journal of Applied Sciences 5 (4): 328-333, 2008

ISSN 1546-9239

(C) 2008 Science Publications

\title{
Experimental Investigation on Three Dimensional RC Infilled Frame - RC Plane Frame Interactions With Slab for Seismic Resistance
}

\author{
Suyamburaja Arulselvan and K.Subramanian \\ Coimbatore Institute of Technology, Coimbatore-641 014, Tamilnadu, India
}

\begin{abstract}
Experimental investigation was planned and conducted to study the influence of brick masonry infill and slab in a three-dimensional reinforced cement concrete frame. In this study, onefifth scale 3D R.C frame representing single story, three bays with central bay brick infill at the sides and a long single bay without infill in the middle of the frame along loading direction and two numbers of two bays at the edges without infill and two numbers of single bay without infill in the transverse direction with slab, has been taken for experimental investigation and the available methods of theoretical analysis for the frames have been carried out. Totally ten columns, eight columns in both ends of the frame along loading direction and two columns in middle along loading direction, were constructed in the frame. Until the cracks developed in infills, the contribution of the infill to both lateral stiffness and strength is very significant. The infill and slab also changes the dynamic characteristics of the frame. The change in lateral stiffness, strength, ductility and natural period of the framed structure due to the presence of infills and slab change the behavior of the building under seismic action. The object of this study was to investigate the behavior of such three dimensional RC infilled frames with slab under seismic loads. Analytical works was done to understand the strength and behavior of these types of frames.
\end{abstract}

Keywords: Earthquake, Stiffness, Deflection and Load carrying capacity

\section{INTRODUCTION}

In this study M20 concrete was adopted for slab and M50 concrete was adopted for columns and beams. High strength Mix design according to IS method was done to achieve the required strength. IS $1893^{[1]}$ code was used to base shear calculation. Yaw-Jeng Chiou et $\mathrm{al}^{\left[{ }^{[2]}\right.}$ have reported the structural behaviour of a framed masonry wall subjected to in-plane monotonic loading is investigated by a full-scale test and the method of discontinuous deformation analysis. Ashok K.Ghosh and Made M.Amde ${ }^{[3]}$ studied analytically the infilled frame. He analysed the frame by using finite element method. Diptesh Das and Murty ${ }^{[4,5]}$ have reported on the Non-linear pushover analysis performed on five reinforced framed buildings with brick masonry infills for the same seismic hazard as per Eurocode8. Henderson ${ }^{[6]}$ have reported a five-year, large and smallscale, static and dynamic experimental research program, in which more than 700 tests were conducted, has demonstrated that unreinforced masonry infills are more ductile and resist lateral loads more effectively than anticipated by conventional code procedures. Portland Pozzolana cement confirming to IS 269-1976 had been used for concreting. Well - graded crushed aggregate and uniformly graded sand were procured and used. Nadreddin.S, El Mezaini ${ }^{[7]}$ studied the reserved strength of reinforced concrete buildings with masonry walls..Due to the complex behavior of such composite structures, experimental research is of great importance to determine the strength, stiffness and dynamic characteristics at each stage of loading

Experimental program general: The experimental investigation consisted of testing one-fifth scale single story model of three dimensional reinforced concrete frame with two numbers of three bays with central bay brick infilled along the loading direction and two numbers of two bays without infill in the other (transverse) direction with slab under static lateral cyclic load. The columns were constructed on the raft foundation. The raft foundation made with sufficient number of circular holes to fix the frame on the test floor. The frame members are designed in such a way that plastic hinges in beams are realized before the failure of columns. The frames were cast with quality raw materials. The three dimensional RC frame model is shown in Fig.1.

Corresponding Author: Suyamburaja Arulselvan, Lecturer, Department of Civil Engineering, CIT, Coimbatore - 641014, India Ph: +919842293245 


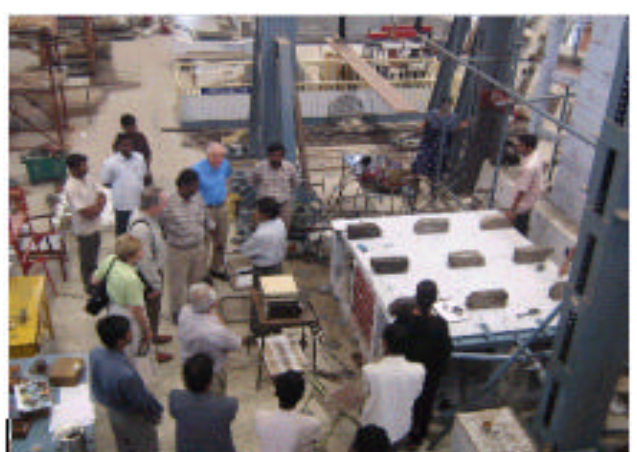

Fig.1: Model and Test set up of frame

Test Set-Up: The models were tested as vertical cantilevers under a cyclic loading program. The schematic diagram of test set-up is presented. It consists of the following arrangements.

Loading arrangement, Instruments for measuring deflection (LVDT, Deflectometer etc.), Rigid body rotation of foundation block, Strain measurements.

Lateral cyclic loading was applied at story level in line with the beams. The reaction frame, which is used for loading arrangements, is rigidly fixed to the test floor. Hydraulic jack of capacity $200 \mathrm{KN}$ were use and it will transfer by line load to the frame. Loads were applied from jack at story level of the frame. Pressure gauge was used to measure the applied load. For the application of load through jack one hand operated oil pump was used for applying load. Twelve LVDT (Linear Variable Differential Transformer) of least count $0.01 \mathrm{~mm}$ and nine deflectometers were used for measuring deflections at story level during the initial stages of loading.

Testing Procedure Testing of Frames: Fig.1 shows the complete test setup adopted for the frame model. The effectiveness of instrumentation set up and the loading were checked in the beginning by loading and unloading the frame with small loads (of the orders of $2.5 \mathrm{KN}$ ) till all the readings was repeatable. The frame was subjected to equivalent static lateral cyclic loading. The loading sequences in the beginning were almost same. The load increment for each cycle was $2.50 \mathrm{kN}$ at all the stages. The deflections were measured at each increment or decrement of load. The strains in steel, concrete and infill were monitored at maximum load of each cycle and at unloading conditions of frame (i.e. when the load is released fully) during all cycles of loading. The formation and propagation of cracks, hinge formation and failure pattern have been recorded. The concrete cubes were tested for $3^{\text {d }}, 7^{\text {th }}$ and $28^{\text {th }}$ day's strength as per IS 516 - 1964. The brick prisms were tested under compression and for modulus of elasticity.

Investigation of Three Dimensional RC Frames: The frame was cast, cured for 21 days. Lifted and erected on the test bed. Brickwork, in 1:4 cement mortar, was constructed on the next day and was cured for a period of seven days. The parameters like load-deflection behaviour and stiffness degradation were considered for study of the behaviour of the frame. Theoretical analyses analogy non - linear finite element method was carried out and the results of these analyses have been compared with the experimental results.

Loading and Load Deflection Behavior: The load deflection behaviour of the frame was obtained in two stages, one in infill bay and the other in plain bay.

Load - Deflection Behavior of Infill Bay: The story deflection versus base shear diagram is presented in Fig.2. and Fig.3 From the hysteretic curve assuming bilinear behaviour, the yield deflection ? y was found to be $9.3 \mathrm{~mm}$. The curve exhibited considerable pinching (the middle part of each hysteretic loop was relatively narrow), as well as some stiffness and strength degradation during same-drift repeat cycles. This behaviour is characteristic of most RC frame connections and is typically attributed to reinforcement bond slip through the joint region, concrete cracking, and/or reinforcement yielding. At the maximum load, the deflection in experiment was $43.1 \mathrm{~mm}$ and in the analytical results it was $9.73 \mathrm{~mm}$ as shown in Fig. 4 and in the table 1. In the experiment, the reinforcement components of the frame was subjected to yielding at every cycle. This was cause for high energy set up in the frame. Also this was the one of the reason to maximum deflection in the frame.

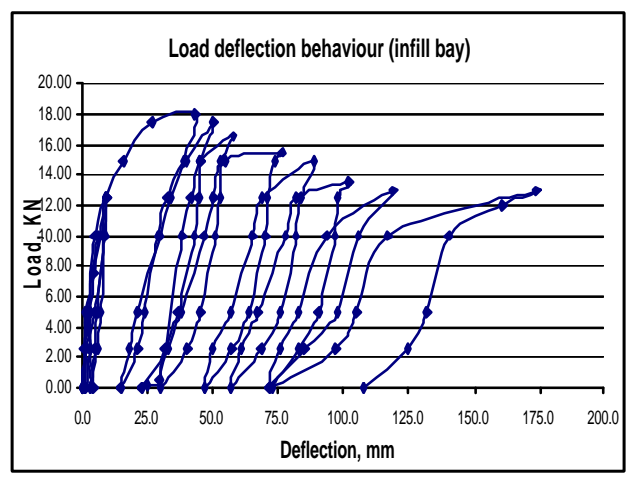

Fig. 2: Hysteretic curves of Base Shear Vs Top story Deflection of three bays with center bay infill 


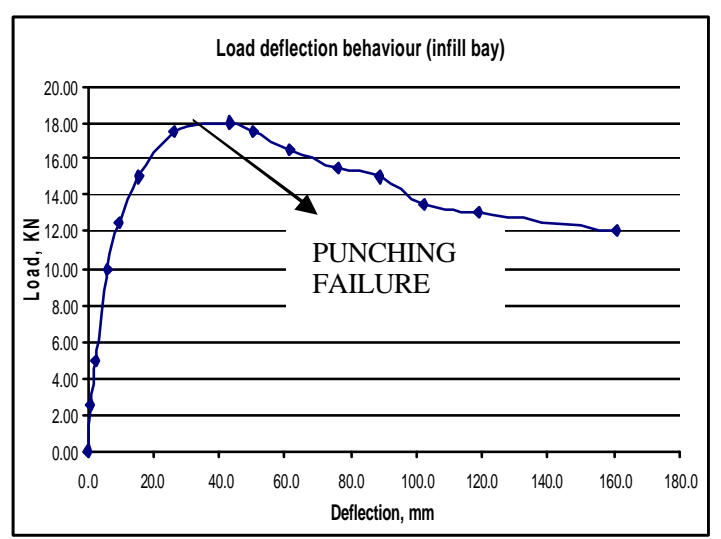

Fig.3: Base shear vs Deflection

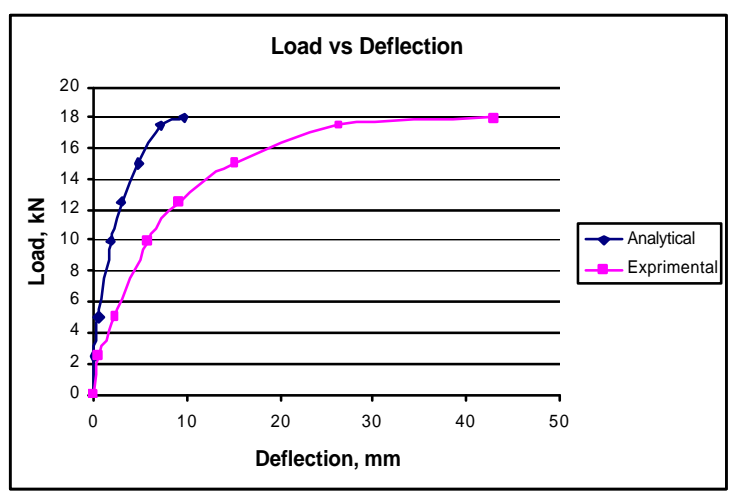

Fig.4: Base shear vs Deflection

Table1: Load vs deflection of infill bay

\begin{tabular}{ccc}
\hline Load, $\mathrm{kN}$ & $\begin{array}{c}\text { Deflection, } \\
\mathrm{mm} \text {, analytical }\end{array}$ & $\begin{array}{c}\text { Deflection, mm, } \\
\text { experimental }\end{array}$ \\
\hline 0.0 & 0 & 0 \\
2.5 & 0.124 & 0.6 \\
5.0 & 0.657 & 2.3 \\
10.0 & 1.922 & 5.9 \\
12.5 & 3.155 & 9.3 \\
15.0 & 4.887 & 15.2 \\
17.5 & 7.22 & 26.4 \\
18.0 & 9.726 & 43.1 \\
\hline
\end{tabular}

Load - Deflection Behavior of Middle Plain Bay: The variation of maximum story deflection with respect to applied lateral load (Base Shear) is presented in Fig. 5 and Fig. 6 The punching shear failure of the frame is indicated in Fig. 6 by sudden drop in lateral load capacity during $7^{\text {th }}$ cycle. At the maximum load, the frame was obtained distinguish deflection and higher energy was stored in this cycle than the previous cycles. This may due to expansion and propagation of micro cracks formed in the frame and the failure of infill and starting of failure of whole 3D frame. At the maximum load, the deflection in experiment was $69.4 \mathrm{~mm}$ and in the analytical results it was $16.59 \mathrm{~mm}$ as shown in Fig. 7 and in the table 2. Yielding and bond failure were one of the reason for this difference in deflection.

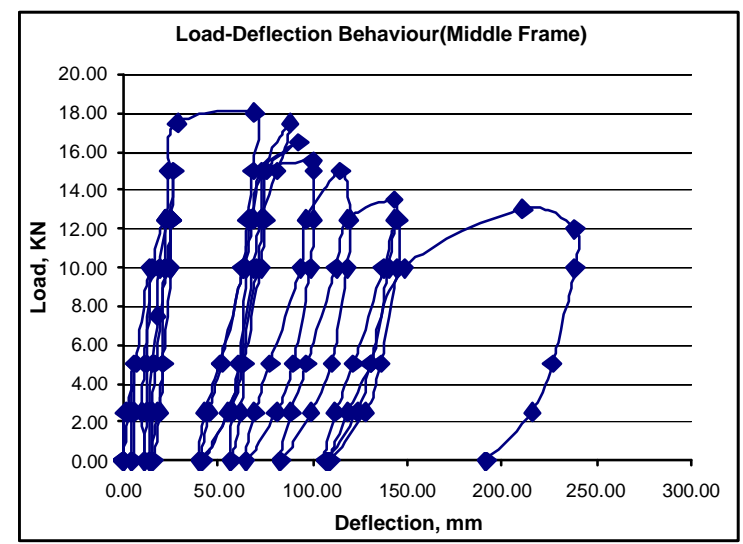

Fig. 5: Hysteretic curves of Base Shear Vs Top Storey Deflection

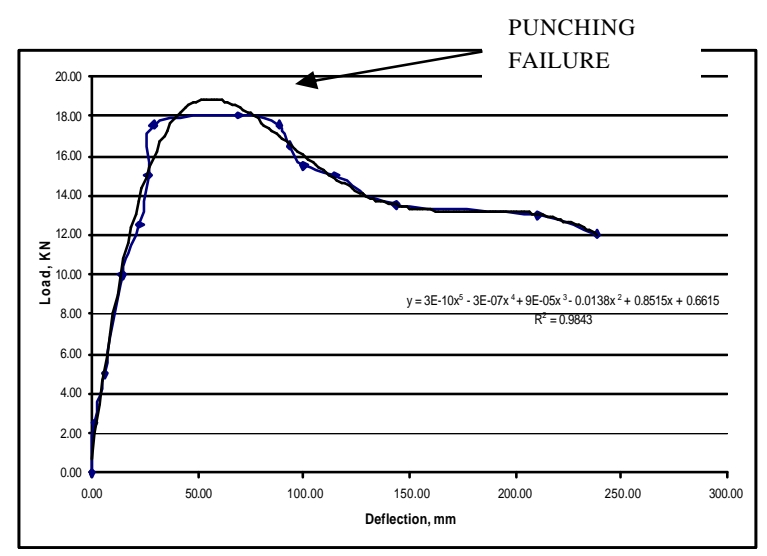

Fig.6: Base shear vs Deflection

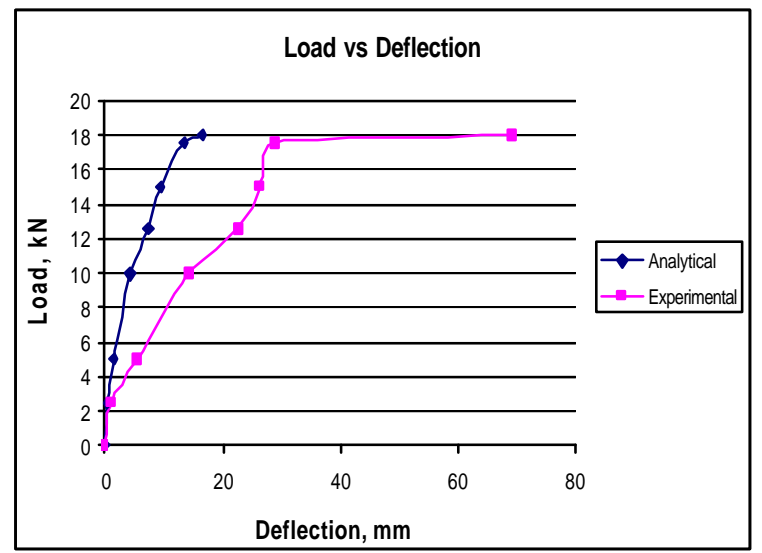

Fig.7: Base shear vs Deflection of middle plain bay 
Table2: Load vs deflection of middle long bay without infill

\begin{tabular}{ccc}
\hline Load, $\mathrm{kN}$ & $\begin{array}{c}\text { Deflection, mm, } \\
\text { (analytical) }\end{array}$ & $\begin{array}{c}\text { Deflection, mm, } \\
\text { (experimental) }\end{array}$ \\
\hline 0.0 & 0 & 0.0 \\
2.5 & 0.396 & 1.0 \\
5.0 & 1.598 & 5.7 \\
10.0 & 4.305 & 14.3 \\
12.5 & 7.394 & 22.5 \\
15.0 & 9.483 & 26.5 \\
17.5 & 13.571 & 28.9 \\
18.0 & 16.589 & 69.4 \\
\hline
\end{tabular}

\section{STIFFNESS DEGRADATIO N}

Three Bays With Central Bay Infill: Stiffness degradation was faster in the first cycle, it was at moderate range from second cycle to seventh cycle and after seventh cycle it was minimum. The stiffness was 1.8 percent of maximum in the last cycle. There was a sudden change in the stiffness curve after seventh cycle. At seventh cycle, the frame was start to failure and the bond between the concrete and steel was collapsed. This was one of the reason of the stiffness reduction in this frame. The stiffness graph is shown in is shown in Fig.8

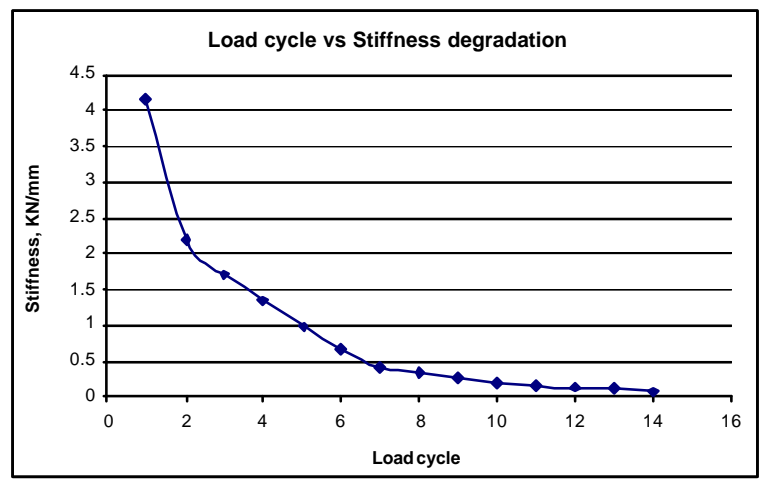

Fig.8: Load cycles-stiffness degradation

Middle Single Bay Without Infill: The stiffness of the middle plain frame for various load cycles were calculated and presented in Table 3 and the variation of stiffness with respect to load cycles is shown in Fig.9. The theoretical maximum stiffness, the experimentally observed stiffness at cracking load and stiffness at service load are also found out. The stiffness of the brick infilled R.C. frame was found to decrease from $2.5 \mathrm{KN} / \mathrm{mm}$ during first cycle to $0.0503 \mathrm{KN} / \mathrm{mm}$ during the thirteenth (final) cycle of loading.

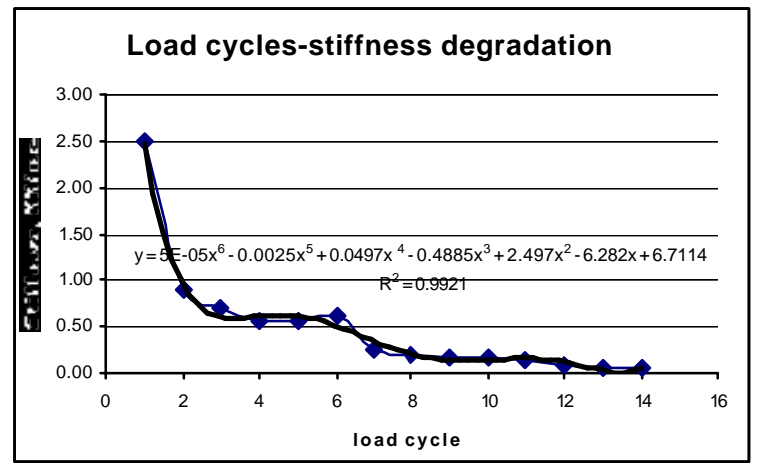

Fig.9: Load cycles-stiffness degradation

Stiffness was in the decreasing order in the consecutive cycles. The trend line equation of the stiffness degradation curve was indicated in the graph

Load Carrying Capacity: Separation cracks were first noticed in the interface between brick infill and beam in the fourth cycle. In the fifth cycle, separation cracks and foundation-column cracks and brick infill failure were found. The maximum load applied on the frame was $18.0 \mathrm{kN}$. Distinguish difference in deflection was obtained in the maximum load from the loads from starting. The different types of cracks witnessed during various loading stages are shown in Fig.10 to Fig.12

Behavi or and Failure Modes: The first crack was witnessed in the interface between brick infill and beam when the base shear was $12.5 \mathrm{KN}$. The cracking occurred during loading reflect the fact that the infilled frame behaved as an integral unit. At failure, the infilled frame exhibited spalling of brick fragments. The formation of plastic hinges in the beam-column joints observed after severe cracking of brickwork. The leeward shear also presented in addition to compression because of the diagonal strut effect of the infill. At the junction of the diagonal strut, leeward column and foundation, the leeward column suffered shear and local buckling. This initiated the final collapse. However separation cracks between frame and infill occurred in all stories panels. The failures occurred in the beamcolumn joints and in the interface between beam-brick infill. Minute line cracks were found in the slab. The three dimensional RC infilled frame at failure stage is shown in Fig. 10 to 12. 


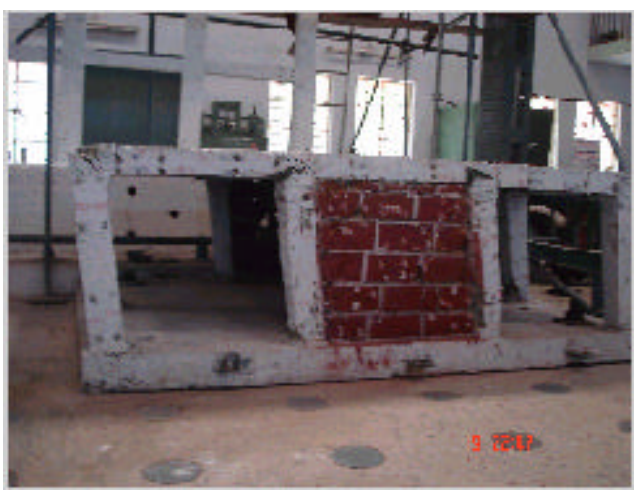

Fig. 10: Cracks and deflected shape of full frame

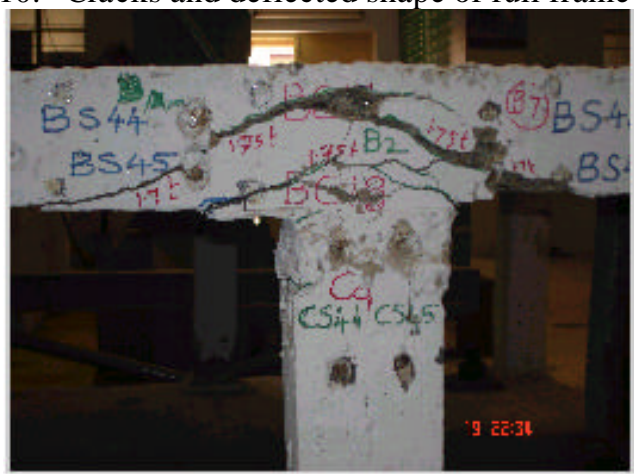

Fig 11: Typical Beams-Column Joint crack in the single long bay

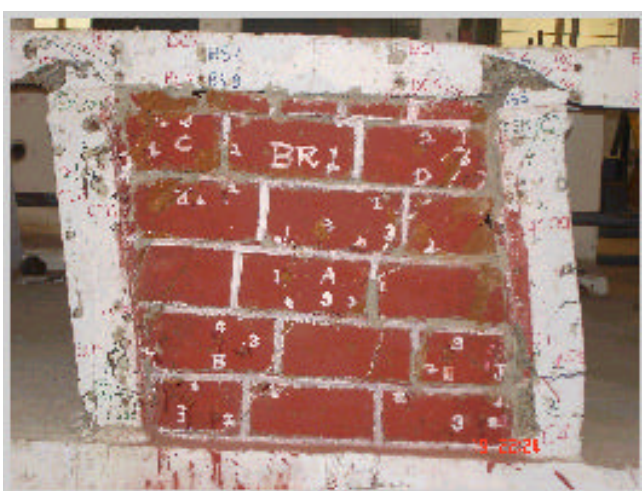

Fig 12: Cracks in infill panel and shear buckling of windward column

\section{DISCUSSION}

In the literature review, the works were carried out in the performance of two dimensional RC frames with and without brick-infill. The tests conducted on two quarter-scale, five storied frames brought out lose of ductility due to infilling. Study of the nonlinear behaviour of reinforced concrete multistory structures on the basis of measured response of four six story, three - bay framed structures, namely a regular bare frame, a discontinuous-column frame, a partially masonry-infilled frame. In this study, three dimensional model frame with slab at one-fifth scale were considered. The behaviour study was done experimentally along loading direction of the frame. The behaviour of two three bays with center bay infill and one long single bay without infill were studied. Load-deflection and stiffness studies were conducted.

\section{CONCLUSIONS}

The frame developed beam and column hinging near beam column interfaces before they reached their maximum story shear force and they eventually failed due to joint shear, exhibiting successive strength drops. The first crack was found in the interface between the beam and the infill, because of low shear resisting capacity of the interface joint. The frame exhibited diagonal crack failure at brick infill at a relatively slow rate of increase before they started to break down. After collapse of brick infill, the infill bay was act as a soft story so that the infill didn't take any load after collapse. The contribution of brick infill was significant up to breaking. It is recommended that brick infill should be considered in the analysis of moment frames, especially in the lateral load resisting systems. Major failures were occurred in by the hinge formation in the column - beam joints. All the beam-column joints were get severe failures. The slab was not much affected in the lateral cyclic loads; it was get deflection due to the combined effect of dead, live loads and lateral loads. The windward column of the infill panel was get shearbuckling crack. The maximum deflection obtained in the central single bay without infill in the middle of the frame along the loading direction. The severe failures occurred in the foundation and column joints due cyclic lateral loading effects. The diagonal cracks were found in the infills. After this diagonal crack, the infill in the bottom story was inactive. Also the infill was separated from the beam after the formation of diagonal crack. The stiffness was higher in three bays with infill in the central bay then the middle single bay. At the final stage, the length of the diagonal was nearly 20 percent greater than the compression diagonal in the brick infill.

\section{REFERENCES}

1. Indian Standard criteria for earthquake resistant design of structures, Part 1: General Provision and Buildings, IS 1893 (part 1): 2002, Bureau of Indian Standards, New Delhi, 2002

2. Yaw-Jeng Chiou Jyh-Cherng Tzeng, Yuh-When Liou, 2006. Experimental and analytical study of masonry infilled frames. Journal of structural Engineering, 125(10), 1109-1117

3. Ashok K.Ghosh and Made M.Amde 2002. Finite element analysis of infilled frames. Journal of Structural Engineering, 128(7), 881-889 
4. Diptesh Das and Murty.C.V.R. 2004. Brick masonry infills in seismic design of RC framed buildings: Part1-Cost implications. The Indian concrete Journal, 78(4) , 39-44

5. Diptesh Das and Murty.C.V.R 2004. Brick masonry infills in seismic design of RC framed buildings: Part1-Cost implications. The Indian concrete Journal. 78(4) , 31-38
6. Henderson.R.C, Fricke K.E., Jones.W.D. Beavers.J.E. Bennett.R.M 2003. Summary of a large and small scale unreinforced masonry infill test program. Journal of Structural Engineering. 129(7), 1667-1675

7. Nadreddin.S, El Mezaini 2005. Reserved strength of reinforced concrete buildings with masonry walls', Computer-Aided Civil and Infrastructure Engineering. 10(5), 172-183. 